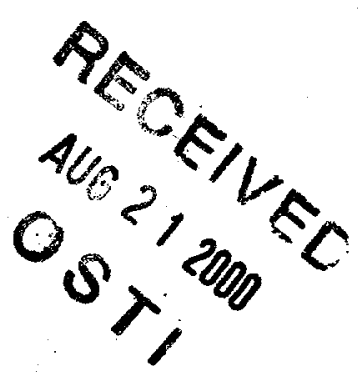

\title{
TCLP Preparation and Analysis of K East Basin Composite Sludge Samples
}

\author{
K. L. Silvers \\ J. J. Wagner \\ R. T. Steele
}

August 2000

Prepared for

the U.S. Department of Energy

under Contract DE-ACO6-76RLO 1830

Pacific Northwest National Laboratory

Richland, Washington 99352 


\section{DISCLAIMER}

This report was prepared as an account of work sponsored by an agency of the United States Government. Neither the United States Government nor any agency thereof, nor any of their employees, make any warranty, express or implied, or assumes any legal liability or responsibility for the accuracy, completeness, or usefulness of any information, apparatus, product, or process disclosed, or represents that its use would not infringe privately owned rights. Reference herein to any specific commercial product, process, or service by trade name, trademark, manufacturer, or otherwise does not necessarily constitute or imply its endorsement, recommendation, or favoring by the United States Government or any agency thereof. The views and opinions of authors expressed herein do not necessarily state or reflect those of the United States Government or any agency thereof. 


\section{DISCLAIMER}

Portions of this document may be illegible in electronic image products. Images are produced from the best available original document. 


\section{Summary}

Sludge samples from the Hanford K East Basin were analyzed by the Toxicity Characterization Leaching Procedure (TCLP) to assist in the appropriate Resource Conservation and Recovery Act (RCRA) designation of this material. Sludge samples were collected by Fluor Hanford, Inc. using the consölidated sludge sampling system (system that allows collection of a single sample from multiple sample locations). These samples were shipped to the Postirradiation Testing Laboratory (PTL, 327 Building) and then transferred to the Pacific Northwest National Laboratory (PNNL) Radiochemical Processing Laboratory (RPL, 325 Building) for recovery and testing. Two sludge composites were prepared, using the consolidated sludge samples, to represent $\mathrm{K}$ East canister sludge (sample KC Can Comp) and K East floor sludge (sample KC Floor Comp). Each composite was extracted in duplicate and analyzed in duplicate following pre-approved ${ }^{(a)}$ TCLP extraction and analyses procedures. In addition, these samples and duplicates were analyzed for total RCRA metals (via acid digestion preparation). The work was conducted in accordance with the requirements of the Hanford Analytical Quality Assurance Requirements Document (HASQARD). A PNNL Quality Assurance Program compliant with HASQARD was implemented for this effort. The results from the TCLP analyses showed that all RCRA metal concentrations were less than the TCLP limits for both the canister and floor composite samples and their respective duplicates.

(a) The Washington State Department of Ecology agreed to the TCLP procedures for preparing and analyzing K East Basin Sludge materials on May 25, 2000. In comparison to EPA-SW-846 Solid Waste Methods, these procedures used smaller sample sizes, based on radiological considerations. 


\section{Introduction}

This report and data package provide the Toxicity Characterization Leaching Procedure (TCLP) results and total Resource Conservation and Recovery Act (RCRA) metals results from the testing and analyses of two $\mathrm{K}$ East $(\mathrm{KE})$ Basin composite sludge samples: $\mathrm{KC}$ Can Comp and $\mathrm{KC}$ Floor Comp. The preparation of two composite sludge samples was performed in response to the Spent Nuclear Fuel letter (Baker et al. 2000, Appendix C) directing the execution of an expedited TCLP testing and analysis campaign associated with KE Basin consolidated sludge samples. The TCLP testing and analyses were performed in the Pacific Northwest National Laboratory (PNNL) Radiochemical Processing Laboratory (RPL, 325 Building) and followed Sampling and Analysis Plan HNF-6479 (Baker et al. 2000). These TCLP analyses were performed to Hanford Analytical Quality Assurance Requirements Document (HASQARD) requirements following PNNL's Quality Assurance Plan for Conducting Analytical Work in Support of Regulatory Programs.

\section{Composite Preparation}

Two KE Basin sludge composite samples were prepared using sludge obtained during the consolidated sludge sampling campaign (Pitner 1999). One composite sample was prepared to represent KE Basin canister sludge and a second to represent the floor sludge. KC Canister Composite (KC Can Comp) was prepared from the three consolidated sludge samples (KC-1, KC-2 and KC-3) collected in 1999 from $\mathrm{KE}$ Basin fuel canister barrels. KC-2 includes sludge from three canister barrels containing moderately damaged fuel. $\mathrm{KC}-3$ includes sludge collected from three canisters containing severely damaged fuel. $\mathrm{KC}-1$ is from a single canister barrel containing severely damaged fuel. In previous testing activities, all of the sludge from $\mathrm{KC}-2$ and $\mathrm{KC}-3$ was combined to form $\mathrm{KC}-2 / 3$. For $\mathrm{KC} \mathrm{Can} \mathrm{Comp,} \mathrm{6/7} \mathrm{of} \mathrm{the} \mathrm{sludge}$ (volume fraction, settled sludge basis) was taken from $\mathrm{KC}-2 / 3$ and $1 / 7$ was taken from $\mathrm{KC}-1$ (i.e., composite was volume weighted based on number of sampling locations).

The KC Floor Composite (KC Floor Comp) was prepared from two consolidated sludge samples collected in 1999: $\mathrm{KC}-4$ and $\mathrm{KC}-5$. $\mathrm{KC}-4$ contains sludge from three locations on the $\mathrm{KE}$ floor in areas adjacent to slotted canister barrels (i.e., in-between the barrels). $\mathrm{KC}-5$ contains sludge from three locations in areas of deep sludge on the main basin floor, away from the canister barrels and away from ion exchange resin. For the composite, the samples were combined as follows (settled sludge, volume basis): $40 \%$ from $\mathrm{KC}-4$ and $60 \%$ from $\mathrm{KC}-5$. These ratios are roughly consistent with the projected ratios of these two sludge types in $\mathrm{KE}$ Basin. KC Floor Comp does not contain sludge from any of the pits in the KE Basin.

The composite sludge samples (settled sludge basis) were submitted for TCLP analysis, and total RCRA metals via acid digestion. Laboratory tracking numbers were assigned to the composite samples to facilitate processing through the RPL. A cross reference between laboratory tracking numbers and sample identification is given in Table 1. 
Table 1. Sample Identification Matrix

\begin{tabular}{|l|l|}
\hline RPL Number & Sample Identification \\
\hline $00-02230$ & KC Can Comp \\
\hline $00-02231$ & KC Can Comp-Dup \\
\hline $00-02232$ & KC Floor Comp \\
\hline $00-02233$ & KC Floor Comp-Dup \\
\hline
\end{tabular}

\section{TCLP Extraction and Analyses}

The KC Can Comp and KC Floor Comp samples were prepared in duplicate for TCLP extraction and analysis in accordance with Procedure PNL-ALO-110. Aliquots of each composite sample were taken in duplicate to determine the weight percent (wt \%) solids prior to initiating the extractions (Procedure PNL-ALO-504). The weight percent solids results are shown in Table 2.

Table 2. Weight Percent Solids Results

\begin{tabular}{|c|l|c|c|c|}
\hline $\begin{array}{c}\text { RPL } \\
\text { Number }\end{array}$ & \multicolumn{1}{|c|}{ Sample ID } & $\begin{array}{c}\text { Wt\% } \\
\text { Solids }\end{array}$ & $\begin{array}{c}\text { Average } \\
\text { Wt\% } \\
\text { Solids }\end{array}$ & $\begin{array}{c}\text { Relative } \\
\text { Percent } \\
\text { Difference } \\
\text { (RPD) }\end{array}$ \\
\hline $00-02230$ & KC Can Comp & 70.52 & 70.12 & 1.16 \\
\hline $00-02231$ & KC Can Comp-Dup & 69.71 & \multirow{2}{*}{36.37} & 1.26 \\
\hline $00-02232$ & KC Floor Comp & 36.14 & \\
\hline $00-02233$ & KC Floor Comp-Dup & 36.60 & \\
\hline
\end{tabular}

In accordance with the TCLP protocol, the sludge samples were filtered to remove free liquid. First, the settled sludge composite samples were carefully transferred from the sample vials to the filtration apparatus using a micro spatula. The sludge materials appeared wet when transferred from the vials, but dried rapidly from exposure to the vacuum air and the high volume of air passing through the hot cell. The hot cell temperature during the filtration and extractions was a constant $25^{\circ} \mathrm{C}$. During vacuum filtration of both the samples and the duplicates no liquid was observed or recovered. The filter paper only showed small areas of wetting from contact with the sludge material being filtered. The filtered solids were recovered along with the filter paper and placed in the sample extraction bottle. It was assumed that the observed weight loss during filtration and sample transfer (excluding sludge material accounted for on spatulas and transfer vials) was water loss from evaporation.

The mass of the TCLP extraction fluid used was based on the filtered solids weight, neglecting any water loss. In accordance with Procedure PNL-ALO-110, Fluid \#2 was determined to be the appropriate extraction fluid. The 20:1 ratio of extract to solids was rigorously maintained for each sample. The composite samples were extracted for just over 17 hours before being filtered. The filtered extracts were acidified using Procedure PNL-ALO-128, and the resulting solution transferred for inductively coupled plasma (ICP) analyses. 
Samples analyzed by ICP/AES (atomic emission spectroscopy) included original and duplicate extracts, matrix spikes for each original sample, extraction blank, extraction spike-blank, duplicate digested aliquots of sample extraction fluids (replicates), and a digestion blank (acids and water only).

Analyses for RCRA/TCLP metals included arsenic, barium, cadmium, chromium, lead, silver, and selenium. Based on discussions with the Washington State Department of Ecology, mercury analyses were not performed. All of the RCRA/TCLP metal concentrations measured were below the TCLP limits. The RCRA/TCLP metal concentrations measured are presented in Table 3.

Table 3. Results of TCLP Analyses

\begin{tabular}{|c|c|c|c|c|c|c|c|c|c|}
\hline RPL or Lab \# & Client ID & $\mathbf{D F}^{(1)}$ & $\underset{(\mu \mathrm{g} / \mathrm{ml})}{\mathrm{Ag}}$ & $\underset{(\mu \mathrm{g} / \mathrm{ml})}{\text { As }}$ & $\begin{array}{c}\mathrm{Ba} \\
(\mu \mathrm{g} / \mathrm{ml})\end{array}$ & $\underset{(\mu \mathrm{g} / \mathrm{ml})}{\mathrm{Cd}}$ & $\underset{(\mu \mathrm{g} / \mathrm{ml})}{\mathrm{Cr}}$ & $\underset{(\mu \mathrm{g} / \mathrm{ml})}{\mathrm{Pb}}$ & $\begin{array}{c}\mathrm{Se} \\
(\mu \mathrm{g} / \mathrm{ml})\end{array}$ \\
\hline TCLP Limit & & & 5 & 5 & 100 & 1 & 5 & 5 & 1 \\
\hline ICP/AES Detection Limit ${ }^{(2)}$ & & & 0.025 & 0.25 & 0.01 & 0.015 & 0.020 & 0.05 & 0.05 \\
\hline $00-02230$ & KC CAN COMP & 6.3 & 0.59 & - & 2.18 & 0.20 & 0.38 & 1.5 & 0.4 \\
\hline 00-02230 Replicate & KC CAN COMP & 6.3 & 0.58 & -- & 2.19 & 0.22 & 0.38 & 1.5 & 0.5 \\
\hline $00-02231$ & $\begin{array}{l}\text { KC CAN COMP } \\
\text { duplicate } \\
\end{array}$ & 6.3 & 0.34 & -- & 2.70 & 0.13 & 0.24 & 1.0 & 0.4 \\
\hline $00-02232$ & KC FLOOR COMP & 6.3 & 0.27 & -- & 6.84 & 0.65 & 1.2 & 0.9 & 0.3 \\
\hline 00-02232 Replicate & KC FLOOR COMP & 6.3 & 0.28 & -- & 6.92 & 0.65 & 1.2 & 1.0 & 0.4 \\
\hline $00-02233$ & $\begin{array}{l}\text { KC FLOOR COMP } \\
\text { duplicate }\end{array}$ & 6.3 & 0.24 & -- & 6.77 & 0.61 & 1.1 & 0.7 & 0.3 \\
\hline Digestion Reagent Blank & Reagents (ALO-128) & 2.0 & - & - & $\cdots$ & -- & - & - & -- \\
\hline Extract Fluid \#2 Blank & $\begin{array}{l}\text { Extraction Fluid \#2 } \\
\text { (ALO-110) }\end{array}$ & 2.0 & - & - & 1.04 & - & -- & -- & -- \\
\hline
\end{tabular}

-- indicates measurement is below detection limit.

(1) DF = dilution factor used in ICP/AES analysis.

(2) Sample detection limit = ICP/AES detection limit $x$ dilution factor (DF).

\section{Quality Indicator Checks for TCLP Analysis}

The quality control (QC) check measurements, relative to the RCRA/TCLP metals reported, were within acceptable tolerance, except as noted below. QC control checks included serial dilution, duplicates, matrix spikes, and post spikes of digested extraction fluid.

With the exception of silver, RCRA/TCLP metal spikes were recovered within acceptance limits. The extraction fluid blank matrix spike recovery for silver was about $35 \%$ (acceptance limit is $80 \%$ to $120 \%$ ). The low silver recovery is caused by chloride present during sample processing. All other RCRA/TCLP metal spikes were recovered within acceptance limits.

The matrix spike recovery in the sample-extract fluid (RPL\# 00-02231 \& 00-02233) for silver was also about $35 \%$ (acceptance limit is $75 \%$ to $125 \%$ ). Some silver was detected in sample aliquots. Even after adjusting the silver concentration based upon the spike recovery (i.e., adjusted value $=$ measured value/spike recovery), the concentration of silver in the samples would still be lower than the TCLP limit of $5 \mu \mathrm{g} / \mathrm{ml}$. (Note: The values for silver in the table have not been adjusted.)

The relative percent difference (RPD) in sample RPL\# 00-02230 and its duplicate RPL\# 00-02231 for silver, barium, cadmium, chromium, and lead exceeded the acceptance limit of $\pm 20 \%$ (RPDs ranged from 
about $21 \%$ to $54 \%$ ). The high RPD values are most likely caused by significant sample heterogeneity. All analytes of interest in sample RPL\# 00-02232 and its duplicate RPL\# 00-02233 were within the acceptance limit of $\pm 20 \%$.

Post-spike recoveries of RCRA/TCLP metals were within the acceptance limit of $75 \%$ to $125 \%$, including silver. A high concentration of uranium (approximately 1500 to $3500 \mu \mathrm{g} / \mathrm{ml}$ ) was present in sample extract fluids.

\section{Total Metals Analyses via Acid Digestion}

Dried sub-samples of KC Can Comp, KC Can Comp-Dup, KC Floor Comp and KC Floor Comp-Dup from the weight percent solids determination were utilized for the acid digestion (PNL-ALO-101) preparation. A small amount of residual material remained following digestion of the KC Floor Comp and KC Floor Comp-Dup (Note: the amount of residual material was not determined). The residual material appeared to be primarily sand. All of the KC Can Comp and KC Comp-Dup samples were completely dissolved.

The resulting acid digest solutions were analyzed by ICP/AES using Procedure PNL-ALO-211. Because of the high concentration of uranium and iron in the samples, analytical dilutions of 5 - to 25 -fold were required to minimize spectral interference. A single element standard of uranium at $500 \mu \mathrm{g} / \mathrm{ml} \mathrm{was} \mathrm{also}$ analyzed. Measurement results of the uranium standard demonstrated that the inter-element correction coefficients for the uranium channel had some small discrepancies. Final sample concentrations reported were corrected off-line by subtracting the apparent analyte concentrations measured in the uranium standard times the ratio of uranium in the sample to the uranium in the $500 \mu \mathrm{g} / \mathrm{ml}$ standard. More detailed information on the correction protocol can be found in Appendix C2.

The results of the ICP/AES for total RCRA metals are provided in Table 4. The data have been adjusted to represent the sludge on an "as settled basis." The ICP data on a dry basis can be found in Appendix C2.

Quality control check measurements were within acceptable tolerance limits, except as noted in Table 5. QC control checks include serial dilution, duplicates, matrix spike, and post spikes.

Detection limits listed in this report may be different than those for acidified water. Detection limits for some analytes are affected by high concentrations of iron and/or uranium present in samples. Spectral interference and recombination continuum effects resulting from high concentrations of uranium, iron and/or aluminum may cause an overestimate in concentration for some analytes.

\section{References}

Baker, R. B., T. L. Welsh, and B. J. Makenas. 2000. Sampling and Analysis Plan for Sludge from the 105-K Basins to Support Transport to and Storage in T Plant, HNF-6479, Rev. 0, Fluor Hanford, Inc., Richland, Washington.

Pitner, A. L. 1999. K East Basin Sludge/Sampling 1999 Campaigns. HNF-4746, Rev, 0, Numatec Hanford Corporation, Richland, Washington. 
Table 4. Results for Total RCRA Metals of KE Basin Floor and Canister Composites

\begin{tabular}{|c|c|c|c|c|c|}
\hline Analyte & $\begin{array}{l}\text { Process } \\
\text { Blank } \\
(\mu \mathrm{g} / \mathrm{g})\end{array}$ & $\begin{array}{c}\text { KC Can Comp } \\
\text { Settled-Wt. } \\
(\mu \mathrm{g} / \mathrm{g})\end{array}$ & $\begin{array}{c}\text { KC Can Comp } \\
\text { DUP } \\
\text { Settled-Wt. } \\
(\mu \mathrm{g} / \mathrm{g})\end{array}$ & $\begin{array}{c}\text { KC Floor Comp } \\
\text { Settled-Wt. } \\
(\mu \mathrm{g} / \mathrm{g})\end{array}$ & $\begin{array}{c}\text { KC Floor Comp } \\
\text { DUP } \\
\text { Settled-Wt. }(\mu \mathrm{g} / \mathrm{g})\end{array}$ \\
\hline multiplier $=$ & 110.8 & 2221.4 & 2731.6 & 562.3 & 791.4 \\
\hline RPL\# $=$ & $00-02230-\mathrm{PB}$ & $00-02230 @ 25$ & 00-02231@25 & 00-02232@5 & $00-02233 @ 5$ \\
\hline Arsenic & -- & NQ & NQ & NQ & NQ \\
\hline Barium & -- & [70] & [65] & [50] & [62] \\
\hline Cadmium & -- & -- & $\ldots$ & 45 & 47 \\
\hline Chromium & $\ldots$ & {$[50]$} & {$[50]$} & 190 & 199 \\
\hline Lead & - & - & -- & [97] & {$[106]$} \\
\hline Selenium & -- & NQ & NQ & NQ & NQ \\
\hline Silver & -- & NQ & NQ & NQ & NQ \\
\hline Uranium & -- & 501000 & 496000 & 39300 & 40600 \\
\hline
\end{tabular}

-- not detected.

[] - below estimated quantitation limit.

NQ - RCRA/TCLP analytes such as arsenic, silver, and selenium were not quantifiable because of high uranium concentration in samples.

Table 5. Quality Assurance Criterion and Indicator Performance for Total Metals Analysis (ICP/AES)

\begin{tabular}{|l|l|}
\hline \multicolumn{1}{|c|}{ QC Parameter } & \multicolumn{1}{|c|}{ Comments } \\
\hline Fivefold Serial Dilution & $\begin{array}{l}\text { Met requirements for all analytes of interest; verified 5-fold dilutions was } \\
\text { within tolerance limit of } \leq 10 \% \text { difference in RPL\# 00-02230 }\end{array}$ \\
\hline Duplicate RPD & $\begin{array}{l}\text { Met requirements. Duplicate samples were within tolerance limit of } \leq 20 \% \\
\text { RPD. }\end{array}$ \\
\hline Post-Spiked Samples & $\begin{array}{l}\text { All post spikes failed in general because the uranium concentration in the } \\
\text { aliquot tested was beyond the upper linear range of uranium, negating the inter- } \\
\text { element correction capability. }\end{array}$ \\
\hline Blank Spike & $\begin{array}{l}\text { Blank spike recoveries were within tolerance limit of } 80 \% \text { to } 120 \% \text { recovery, } \\
\text { except for silver and selenium. Silver recovery was less than } 1 \%, \text { and selenium } \\
\text { recovery was just below tolerance limit (78\%). Low recovery for silver is } \\
\text { likely a result of using an insufficient amount of hydrochloric acid during } \\
\text { processing. The reason for low selenium recovery is not known. }\end{array}$ \\
\hline Matrix Spiked Sample & $\begin{array}{l}\text { Matrix spike recoveries were was within tolerance limit of 75\% to 125\%, } \\
\text { except for silver. Low recovery of silver (<1\%) was most likely due to the } \\
\text { insufficient amount of hydrochloric acid used during processing. }\end{array}$ \\
\hline $\begin{array}{l}\text { Quality Control Calibration Check } \\
\text { Standards }\end{array}$ & $\begin{array}{l}\text { Met requirements for all analytes of interest. Concentrations of all analytes of } \\
\text { interest were recovered within tolerance of } 90 \% \text { to } 110 \% \text { for standard } \\
\text { QC-MCVA. QC-SSTMCV recoveries for all analytes measured were within } \\
\text { tolerance limits. ICP98.0 (calibration blank) measurement results were } \\
\text { acceptable, within three times detection limit. Uranium, single element } \\
\text { standard at 500 } \mu \text { g/ml, was within } 99 \% \text { of expected value. }\end{array}$ \\
\hline High Calibration Standard Check & $\begin{array}{l}\text { Met requirements for all analytes of interest. High calibration concentrations } \\
\text { were within tolerance limit of } \pm 5 \% \text { accuracy. }\end{array}$ \\
\hline Process Blank & $\begin{array}{l}\text { Met requirements for all analytes of interest. All analytes of interest were } \\
\text { within tolerance limit of either } \leq \text { EQL or < }<\% \text { of sample concentration. }\end{array}$ \\
\hline Laboratory Control Standard & Laboratory Control Standards were not prepared. \\
\hline
\end{tabular}

